\title{
The Evaluation Index System of Internationalization of Chinese Higher Vocational Education in the era of Knowledge-based economy
}

\author{
TANG Zhi-wen \\ School of Mechanical Engineering, Hunan International Economics University, Changsha, Hunan, China, 410205 \\ E-mail:tangzhiwen1973@126.com
}

\begin{abstract}
Based on the research of related literatures on internationalization of higher education in the era of knowledge-based economy, this article divides internationalization of higher education into eight types of indicators: international philosophy and strategic planning, international organization setting, international staff elements, internationalization of curriculum, Sino-foreign cooperative education, international teaching and scientific research management, international social repercussion and the fusion of internationalization and nationalization. This paper constructs the evaluation index system and provides a perspective for the comprehensive assessment of internationalization of higher vocational education in the era of knowledge-based economy.
\end{abstract}

Keywords-indicator system; internationalization; higher education; knowledge-based economy

\section{INTRODUCTION}

In the early 1990, the knowledge economy was only a concept in our mind. However, from then on, the effects of economic globalization could no longer be ignored. As human society evolves from the era of agricultural economy to industrial economy, until in the current era of knowledge economy, different types of education around human beings are also emerging and developing. Walter W. Powell and Kaisa Snellman (2004) defined the knowledge economy as production and services based on knowledge-intensive activities that contribute to an accelerated pace of technological and scientific advance as well as equally rapid obsolescence[1]. In the current era of knowledge-based economy, the emphasis must be not only on the structure of educational institutions, but also on their content. All over the world, both in developed and developing nations, higher education is believed to be the key to the continuing growth of national economies. As far as China is concerned, with the rapid socio-economic changes and the continuous progress of the popularization of higher education in recent years, China's higher vocational education is also entering a period of rapid expansion and is facing major challenges to its governance systems, curriculum, institutional settings, mission focus, financing, teachers structure, external relations, and enrolling problems. The main task of this article is to preliminarily study the evaluation system of the internationalization of higher vocational education in China. The remaining structure is organized as follows: Section 2, we will summarize the relevant literature both at home and abroad. Then the evaluation system of the internationalization of higher vocational education in China is constructed from two major-level perspectives. The last section is concluding discussion.

\section{REVIEW OF LITERATURE}

In discussing where higher education is going, many experts and scholars have discussed on massification, internationalization, accountability and governance, industrialization, and rankings and world-class universities (Altbach,2005; Kerry J. Kennedy,2003; Zusman,2005; Fatemeh Behjati Ardakani., et al,2011) [2] [5]. Kerry J. Kennedy (2003) found that higher education governance is a key policy issue in the $21^{\text {st }}$ century, and 'deliberative partnerships' is one positive way of reconstructing university governance for the future[3]. Fatemeh Behjati Ardakani (2011) studied and compared the efforts in different countries for the internationalization of higher education systems, and found that international curriculum is in fact the most important aspect of the internationalized higher education systems[5]. Simon Marginson (2010) explored the higher education in the global knowledge economy, and summarized six conclusions from his analysis[6].

In China, higher education is mainly carried out in the ordinary full-time universities or colleges, and composed of university education and vocational education. A handful of scholars have explored higher vocational education in China. Based on SSR model, Min Yang (2010) investigated the practice of entrepreneurship in higher vocational education, and concluded that the specific implementation of the key includes classroom teaching, network education, projectoriented learning mode and free team[7]. Pingjian Yan, Huizhe Yan \& Lihua Ma (2009) studied on model and mechanism of higher vocational education in the rural, and some suggestions such as bringing up new farmers and developing rural human resources were discussed in this paper[8]. Zhenhua Liu (2011) explored the background and introspection of higher vocational education reforms in China, and showed that the fundamental objective of higher vocational education is promoting the holistic development of students and providing students with the proper education[9]. Quite a few scholars have studied on the evaluation of higher vocational education based on different theories and methods. Hou Ming-Wei \& Zhang Yan-Ru (2011) researched on the evaluation method in graduation design of engineering students in higher vocational education based on extensive theories[10]. With a higher vocational colleges as an example, Gao Hong-Bo \& Liu Xuan (2011) studied on optimizing quality of higher vocational education based on principal components analysis of data mining, and provided some suggestions on how to improve the quality of 
higher vocational education[11]. Xiang Wu., et al (2012) investigated how to improve higher vocational college education quality assessment, and concluded that higher vocational college should highlight the practical teaching characteristic, and build an analysis evaluation mechanism[12].

The above literatures mainly discuss the characteristics of higher education, including the governance and internationalization of higher education etc. In addition, the researches on vocational education are growing, but most of which rarely involve in the evaluation index system of internationalization of higher vocational education in China. This article aims to investigate the evaluation index system of internationalization of Chinese higher vocational education by using 8 first-class indexes and 20 second-class indexes.

\section{CONSTRUCTING THE EVALUATION INDEX SYSTEM OF INTERNATIONALIZATION OF CHINESE HIGHER VOCATIONAL EDUCATION}

Determining evaluation elements is the key to establish evaluation index system. Higher vocational education has experienced about 20 years in China, and has been a new type of higher education with Chinese characteristics. The internationalization of higher vocational education is the process of putting the transnational and cross-cultural concepts, and higher vocational education, scientific research, social service together. In accordance with the general principles of the design of the evaluation index system, and based on the existing research achievements, we get a series of key elements that used to evaluate the internationalization of higher vocational education in China. Concretely speaking, the evaluation index system of internationalization of Chinese higher vocational education is composed of 8 first-class indexes, 20 second-class indexes, and 49 third-class indexes.

\section{A. International philosophy and strategic planning}

Just like the reform of general higher education, the preliminary requirement of higher vocational education reform is transforming idea. As the internationalization of China's higher vocational education started late, in the areas of international exchange and cooperation, the relatively old ideas have already existed objectively. Therefore, setting up the international philosophy of higher vocational education, formulating corresponding international strategic planning, are the first choices for the internationalization of higher vocational education in China.

1) International philosophy. The internationalization of higher vocational education concept includes three-third indexes, which lay great stress on the international awareness, attitude and concept of professional teachers, general managers and students in higher vocational college. International awareness of professional teachers, general managers and students is directly related to the process of the internationalization of higher vocational education. For the professional teachers, they should be aware of the world latest development about the disciplines and specialties. As to the school leaders and general managers, the fundamental purpose is to establish international strategic sense of identity, and guide the teaching, scientific research and social service work with an international vision. The students of higher vocational colleges also should have international concept, and strive to become global high-quality talents.

2) International strategic planning.International strategic planning is the action program of the internationalization of higher vocational education in China. Making good strategic planning is a prerequisite in promoting the reforms of teaching, training and scientific research in higher vocational colleges. As a second-grade index, international strategic planning (B12) includes three third-indexes, which cover the developing trend, target, content, and guarantee measures of the internationalization in Chinese higher vocational colleges over a certain period of time.

\section{B. International organization setting}

Organization is the fundamental guarantee for implementing the internationalization of higher vocational education. Almost all international affairs in higher vocational colleges are required to be finished by a specialized organization system. In China, the international organization of higher vocational colleges mainly includes three parts as follows: international affairs office, schoollevel international affairs committee, international exchange department. Eight third-grade indexes have been constructed to investigate international organization setting in Chinese higher vocational colleges.

1) International Affairs office. International Affairs office is an important functional department in higher vocational colleges, and mainly responsible for implementing the international strategic planning, expanding the international education market and assisting overseas recruitment.

2) School-level international affairs committee. Schoollevel international affairs committee is the highest decisionmaking institution in higher vocational education, and the main duties are as follows: establishing related systems, carrying out related activities, making the composition of the committee members reflect internationalization.

3) International exchange department. International exchange department is an important guarantee for the globally optimal configuration of higher vocational education resources. Not only "international exchange and reception management”, “visiting job management”, "dispatched work management", but also "international communication ability training of backbone teachers" is the core function and task of international exchange department.

\section{International staff elements}

Personnel factor mobility is one of the most important contents during the internationalization course of higher vocational education. We can use two second-grade indexes to evaluate the internationalization of Chinese higher vocational education. One is the internationalization of teaching staff, the other is the internationalization of students' structure. Concretely speaking, the former includes four third-grade indexes, the latter includes three third-grade indexes. Foreign teachers and returned overseas talents are 
playing an important role in promoting the internationalization of Chinese higher vocational education. At the same time, double-professional teachers, backbone teachers, young and middle-aged excellent teachers have played a much more important role than foreign teachers and returned overseas talent at the present stage. The comparative specific analysis results are shown in Table 1. International students' structure is an important indicator that reflecting a school is an international school. In Chinese higher vocational college, the proportion relationships between foreign students and all students in school, interchangeable students with foreign vocational colleges and all students in school have better reflected the internationalization of students' structure.

\section{Internationalization of Curriculum}

Internationalization of the curriculum is regarded as a basic way to realize internationalization, improve teaching and scientific research, cultivate international talents. As a fundamental first-grade index, internationalization of the curriculum is made up of four second-grade indexes, and includes eight third-grade indexes. From the corresponding results shown in Table 1 , we can easily find that the original textbook and bilingual education, foreign language and culture courses are the foundations of "internationalization of the curriculum”. Furthermore, international and advanced teaching method, international issues in the curriculum are also important for "internationalization of the curriculum", which should be paid attention to.

\section{E. Sino-foreign cooperative education}

Along with the continuously increased exchange and cooperation between different countries' higher vocational education all over the world, Sino-foreign cooperative education has become an important way to realize internationalization of higher vocational education in China. In this article, the first-grade index of "Sino-foreign cooperative education” includes three second-grade indexes and seven third-grade indexes, most of which are about the cooperation in running schools at home and abroad. Through these evaluation indexes, we can easily discover that Chinese-foreign in running schools in higher vocational colleges is still in the exploratory phase at present. It must be pointed out that "Sino-foreign cooperative education management" is very important in Sino-foreign cooperative education. However, China's vocational colleges often do not attach importance to Sino-foreign cooperative education management in the process of their internationalization.

\section{F. International teaching and scientific research management}

From a neo-liberal perspective, the World Bank stressed three key factors to ensure quality, efficiency and equity in tertiary education (including higher vocational education): (1) a coherent policy framework; (2) an enabling regulatory environment; and (3) appropriate financial incentives (World Bank, 2002). This paper emphasizes the importance of international teaching and scientific research management, especially international teaching management. As a second-grade index, international teaching management includes three basic items. Seen from Table 1, we can find that Chinese higher vocational colleges have paid more attention to practice teaching quality management, multimedia teaching management, teaching management system reform and new course reform from an international perspective. Comparatively, international scientific research management has not received the corresponding attention. Obviously, it is determined by the objective reality of the internationalization of higher vocational education in our country at present.

\section{G. International social repercussion}

Essentially, the internationalization of higher vocational education is the process of optimizing the allocation of educational resources between the sovereign states according to market principles. From the international social repercussion of Chinese higher vocational education, we can judge the disposition effect of education resources. International social repercussion can be reflected from two respects: one is "the employments in higher vocational college"; the other is "the international social influence of higher vocational college”. However, employment problem is obtained more attention in China's higher vocational colleges so far. Even worse, many Chinese higher vocational colleges are concerned not the quality of employment but the number of jobs.

\section{$H$. The fusion of internationalization and nationalization}

Internationalization of higher vocational education should be based on nationalization. The objective of China's higher vocational colleges is not only internationalization of nationalization but also the fusion of internationalization and nationalization. On the one hand, the internationalization of higher vocational education should be based on Chinese national culture and national education. On the other hand, Chinese higher vocational education should go to the world based on the nationalization.

\section{CONCLUDING DISCUSSION}

China's higher vocational colleges should carry out the strategy of internationalization timely based on their objective reality. In particular, we should set up the philosophy of internationalization and industrialization of higher vocational education, attract and draw lessons from the successful experience of developed countries in higher vocation education, push forward the internationalization of Chinese higher vocational education continuously in a planned and systematic way, so as to improve the schoolrunning level and the students' ability.

In a word, we have preliminarily constructed the evaluation index system of "internationalization of higher vocational education” in China (see Table 1), which is based on the relevant theoretical research achievement and development practice on internationalization of higher vocational colleges. However, as the internationalization of China's higher vocational education is just at the beginning stage, the evaluation index system established in this article is preliminary in nature, needs to be improved along with the internationalization of Chinese higher vocational education. 


\section{REFERENCES}

[1] Walter W. Powell and Kaisa Snellman.(2004). The Knowledge Economy. Annual Review of Sociology,30:199-220.

[2] Altbach, P.G. (2005). Patterns in higher education development. In P.G. Altbach, R.O. Berdahl, \& P.J. Gumport (Eds.), American higher education in the twenty-first century(2nd ed., PP. 15-37). MD: The Johns Hopkins University Press.

[3] Kerry J. Kennedy. (2003). Higher Education Governance as a Key Policy Issue in the 21st Century. Educational Research for Policy and Practice, 2:55-70.

[4] Zusman, A.(2005). Challenges facing higher education in the twentyfirst century. In P.G. Altbach, R.O. Berdahl, \& P.J. Gumport (Eds.), American higher education in the twenty-first century(2nd ed., PP. 115-160). MD: The Johns Hopkins University Press.

[5] Fatemeh Behjati Ardakani., Mohammad Hossein Yarmohammadian., Ahmad Ali Foroughi Abari \& Koroush Fathi.(2011). Internationalization of higher education systems, 15:1690-1695.

[6] Simon Marginson. (2010). Higher Education in the Global Knowledge Economy. Procedia Social and Behavioral Sciences, 2: 6962-6980.
[7] Min Yang.(2010). Practice of Entrepreneurship in Higher Vocational Education Based on SSR Model. 2010 International Conference on Educational and Information Technology (ICEIT 2010), pp.16-19.

[8] Pingjian Yan ., Huizhe Yan \& Lihua Ma.(2009). Research on Model and Mechanism of Higher Vocational Education in the Rural. 2009 International Conference on Information Management, Innovation Management and Industrial Engineering, pp.214-217.

[9] Zhenhua Liu.(2011). Background and Introspection of Higher Vocational Education Reforms in China. Engineering Education and Management, LNEE 111, pp.181-186.

[10] Hou Ming-wei \& Zhang Yan-ru.(2011). Research on evaluation method in graduation design of engineering students in higher vocational education based on extension theories, pp.100-102.

[11] Gao Hong-bo \& Liu Xuan (2011). Research on Optimizing Quality of Higher Vocational Education Based on Principal Components Analysis of Data Mining - with a higher vocational college as an example. 2011 International Conference on Intelligence Science and Information Engineering, pp.534-537.

[12] Xiang Wu, Yan Chen, Jie Zhang \& Yi Wang.(2012). On Improving Higher Vocational College Education Quality Assessment. 2012 International Conference on Medical Physics and Biomedical Engineering, Physics Procedia 33: 1128-1132.

Table 1. The index systems of internationalization of higher education in China

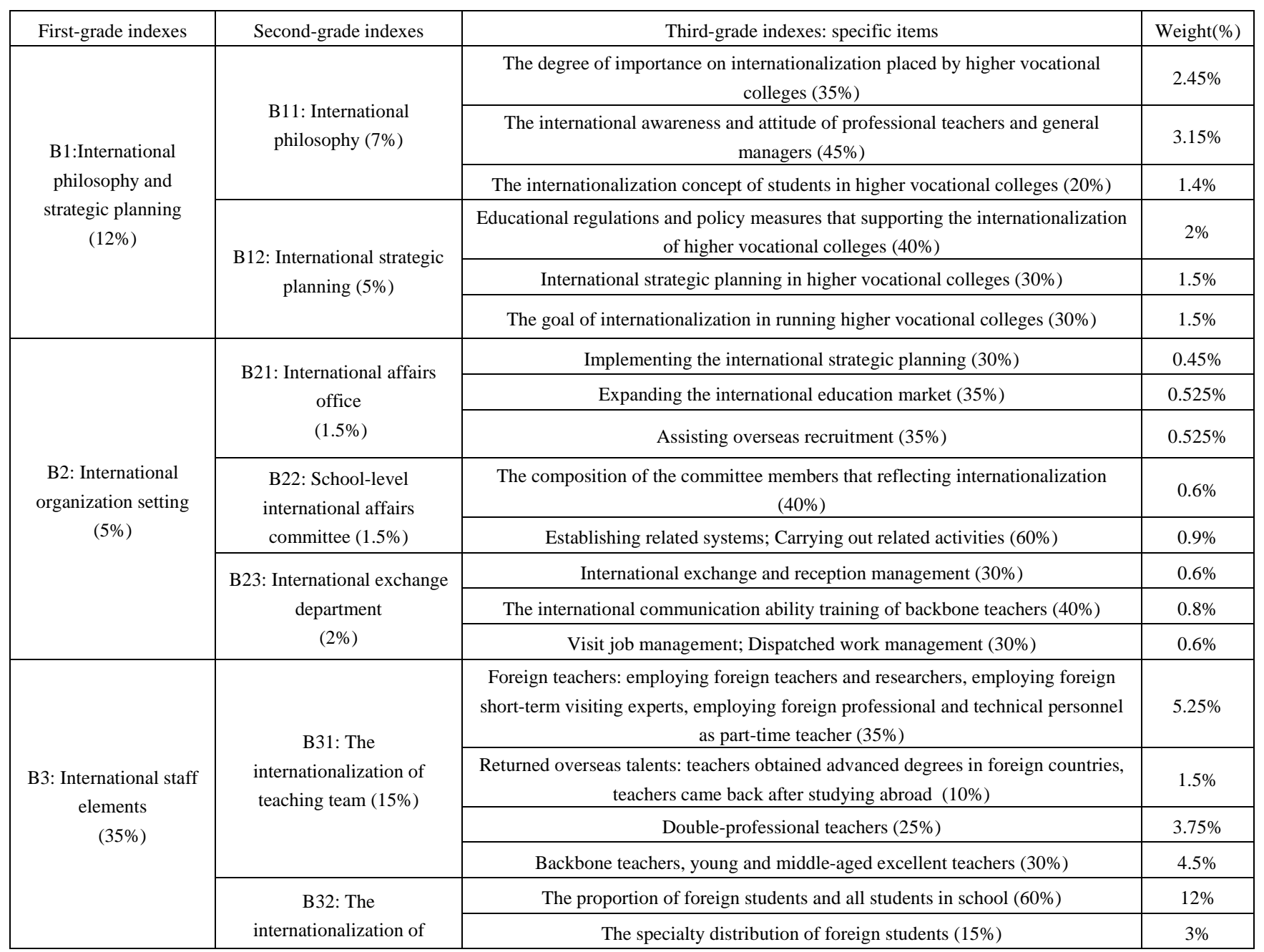




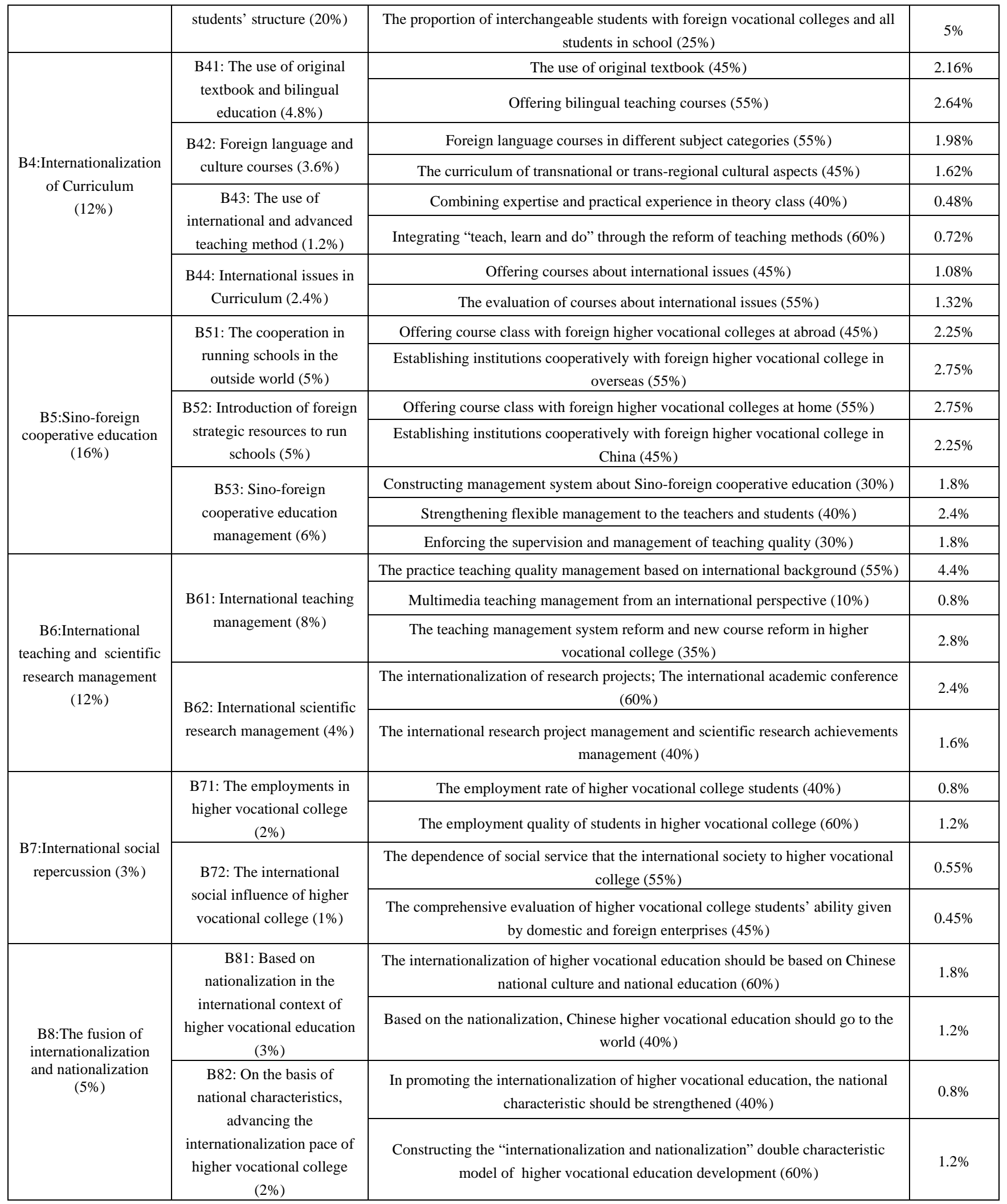

